\title{
Republicans, Catholics and the West: Explaining the Strength of Religious School Aid Prohibitions
}

\author{
Ursula Hackett \\ Department of Politics and International Relations, University of Oxford \\ ursula.hackett@politics.ox.ac.uk
}

\begin{abstract}
This paper has been accepted for publication and will appear in a revised form, subsequent to editorial input by Cambridge University Press, in 'Politics and Religion' published by Cambridge University Press.
\end{abstract}

Copyright: Cambridge University Press (2013)

\begin{abstract}
In the current polarized political climate there is heightened attention paid to the American state constitutional provisions known as 'Blaine Amendments' or 'No-Aid Provisions' which were passed between 1835 and 1959 to prohibit public aid to religious schools. Judgements about No-Aid Provisions have largely been made by scholars on an ad hoc basis using narrative-based historical accounts, emotive language and without clear classificatory criteria. Using content analysis this paper constructs the first quantitative scale of No-Aid Provision strength and subjects it to statistical treatment to explain why some prohibitions are much stronger than others. It finds that larger Catholic populations, Republican dominance and Federal Enabling Acts make No-Aid language more strident. In so doing this paper adjudicates between competing explanations for No-Aid Provision strength in a way that illuminates the interaction of politics, religion and education in America.
\end{abstract}


Remarkable disagreement exists amongst scholars on the subject of "Blaine Amendments" or "No-Aid Provisions," the passages in US state constitutions prohibiting public aid to religious schools. The No-Aid Provisions were created in the nineteenth- and early twentieth-centuries when many American public schools used the King James Bible and mandated the singing of Protestant hymns, practices that Catholics and other religious groups could not accept. They set up private schools to educate their children in their own religious traditions and requested public funds to support them. A ban on such appropriations for private religious schools was formulated by Senator James Blaine, whose proposed federal constitutional amendment failed in 1876 , and by state policymakers who passed the state NoAid Provisions between 1835 and 1959.

There is no scholarly consensus as to the number of such amendments. Kinzer lists "at least 24," Kemerer finds 33 and Gedicks, 37 (Gedicks 2004, 85; Kinzer 1964, 12; Kemerer 1997, 154). Although many scholars acknowledge that state "Blaine Amendments" are couched in different language and come in varying strengths (Heytens 2000; DeForrest 2003; Garnett 2004; Johnson 2008), there is also a tendency to treat such provisions as similar products of the 1870-1890 period and the personal intervention of James Blaine, a dangerously narrowing tendency given that these amendments have been passed throughout much of American history. This paper uses the term "No-Aid Provisions" rather than "Blaine Amendments" in order to acknowledge this wide historical spread.

Scholars' judgements about the relative strength of No-Aid Provisions have largely been made on an ad hoc basis with no clear classificatory criteria and consequential imprecision and uncertainty. Moreover, No-Aid Provisions have enjoyed considerable attention from legal scholars and historians but political scientists have mostly ignored them. Historians have argued that state No-Aid Provisions resulted from Republican dominance of state offices and Federal Enabling Act requirements for newer Western states, anti-Catholic 
bias (Stern 2004) or, alternatively, a commitment to church-state separation (Green 2004). This paper investigates these historical accounts, here termed "Republicans, Catholics and the West," by constructing the first quantitative scale of No-Aid Provision strength and subjecting it to statistical treatment to explain why some prohibitions are much stronger than others.

The construction of a scale for No-Aid Provisions strength offers a more nuanced understanding of a widespread but frequently misunderstood constitutional phenomenon. It enables testing of the causes of No-Aid Provision adoption and their consequences for modern patterns of aid for children at religious schools. There are three advantages of providing a quantitative scale of No-Aid Provision strength, rather than the narrative-based investigations prevalent in the literature: First, the quantitative tools of political science can help resolve conflicting interpretations of No-Aid Provisions based on normative histories. The scale enables scholars to understand the provisions in context and to answer such questions as the following four:

1) Were the No-Aid Provisions simply the result of what Green calls "a...contemplative discussion over the meaning of church-state relations in America," (Green 2012, 199) or were they, in Justice Thomas's words, "born of bigotry" against Roman Catholics (Thomas 2000, 530:6)?

2) Did anti-Catholicism and Republican dominance affect the stridency and scope of the religious school aid ban?

3) How much stronger are, for example, California, Michigan or Oklahoma's bans on religious school aid than Wisconsin's, Alabama's or Florida's, and why?

4) Are strong No-Aid Provisions a bigger barrier to voucher scholarships, textbook loans and transportation for children at religious schools than weak ones? 
Such questions are impossible to answer without a comprehensive survey of No-Aid Provisions and the creation of a quantitative scale of No-Aid Provision strength.

Secondly, constructing a scale of No-Aid Provision strength enables examination of the extent to which the slogan "A Wall of Separation between Church and State" (Jefferson 1802) has ever been valid in the US states. The creation of a strength scale, which has a normal distribution, undermines the absolutist language of Church/State separation prevalent in American public discourse. It prompts commentators to move beyond these rhetorical flourishes towards a more complex understanding of the relationship between religion and government.

Thirdly, a scale of No-Aid Provision strength is invaluable to the burgeoning literature on school choice, educational policymaking and No Child Left Behind reauthorization. There is widespread scholarly agreement about the capacity of legal provisions in state constitutions to affect public policy (Fusarelli 2003; Peterson and Campbell 2001). Fusarelli, for example, documents the way anti-voucher coalitions use NoAid Provisions to block voucher plans (Fusarelli 2003). Judges assess the strength and coverage of state No-Aid Provisions to strike down or uphold transportation, text book loans, tax credit and voucher schemes for children at private religious schools. Before one can understand the causal significance of No-Aid Provisions, it is necessary to know how many there are, where they are, why they are there and what they are like. None of these points has been systematically dealt with by the existing legal-historical accounts. This research is the first to address them using the techniques of modern political science.

While all state No-Aid Provisions serve fundamentally the same purpose - to prohibit public funding to denominational educational institutions - the diversity of No-Aid Provisions in stridency and scope can be measured and analysed statistically. Court decisions have recognized these differences and have turned upon close distinctions in language. For 
instance in Matthews $v$ Quinton the Alaskan Supreme Court found that since the transportation was a "direct benefit" to the non-public school it violated the state's prohibition of aid for the "direct benefit" of religious institutions (Arend 1961, 362:5), but in Honohan v Holt an Ohioan Common Pleas Court concluded "that the indirect benefits resulting to such school from bus transportation of students to and from school is not 'support' of such 'place of worship' within the purview of [the Ohioan No-Aid Provision] constitutional provision." (Leach 1968, 17:6) Demonstrably, such distinctions between NoAid Provisions prohibiting "indirect and direct" aid and merely "direct aid" are consequential.

No-Aid Provisions "take several forms, employ diverse terms, and are integrated and applied in different ways, with varying effects." (Garnett 2004, 49) For example, Iowa's NoAid Provision refers to the prohibition of funds to "an establishment of religion"; Alabama's to "sectarian or denominational schools"; Alaska's to a "religious or other private educational institution" and Michigan's to "nonpublic schools." "Sectarian" could refer to religious sects or to religious denominations more generally; "Nonpublic" includes all non-religious private schools as well as religious ones. "An establishment of religion" is a phrase loose enough to include both schools and other institutions run by religious organizations. Slight differences in legal language have great import where provisions are ambiguous and accordingly, highly contested.

Challenges to No-Aid Provisions are increasingly recurrent, through litigation, ballot initiative or legislative action. The highly charged nature of No-Aid Provision disputes resembles judicial action on prayer in schools, sex education and intelligent design in the degree of emotion it inspires and its public policy significance. In November 2012 for example, Florida's citizens rejected a ballot initiative that would have eliminated the state's No-Aid Provision and replaced it with anti-discrimination language. If the ballot initiative 
had passed it would have affected many areas of faith-based provision and not just schools: health-care, child-care, social services and correctional programmes in prisons. The breadth of public policy for which No-Aid Provisions have become significant lends urgency to this quest for systematic treatment. Given the rapid expansion of education tax credit and voucher laws in the states ${ }^{1}$, all of which cover private religious schools, a thorough investigation of No-Aid Provisions is clearly required.

\section{The Landscape of Religious School Aid Prohibitions}

This paper uses an expansive definition of what constitutes a prohibition of aid to religious schools: all provisions in a state constitution that prohibit the use of public funds for religious schools, whether or not the provision was proposed by Senator James G. Blaine or during the time Blaine was active in political life (1863-1892). Hence the definition includes provisions such as Article 1, Section 5 of Michigan's 1835 Constitution: “No money shall be drawn from the treasury for the benefit of religious societies, or theological or religious seminaries," which was passed forty years before Senator Blaine proposed a federal religious school aid amendment. It also includes Article 7, Section 1 of Alaska's 1959 Constitution "Schools and institutions...shall be free from sectarian control. No money shall be paid from public funds for the direct benefit of any religious or other private educational institution." which was passed more than sixty years afterwards.

There are three main advantages of this expansive definition: first, it includes all prohibitions of aid to religious schools rather than the far narrower subsection typically surveyed by scholars; only around half of all No-Aid Provisions were passed between 1870 and 1900. Secondly, it helps to avoid the relegation of this topic to history and encourages comparative investigation that does not simply centre on the specific conditions and political

\footnotetext{
${ }^{1}$ There have been fourteen new state tax credit and voucher programmes created in the past two years, six of them in 2012
} 
personalities of the late nineteenth century. Thirdly, it focuses scholarly attention on the substantive meaning of the amendments.

Several legal scholars have classified religious school aid provisions in terms of strength using relevant jurisprudence. The resulting classifications are limited in explanatory power. Kemerer classified No-Aid Provisions as "Restrictive," "Permissive" or "Uncertain" according to both the constitutional language and the legal context or case law (Kemerer 1997). Of the 33 "Blaine Amendments" he identifies, 21 are classified as "Uncertain," which limits the appeal of the typology as a basis for comparison. Moreover, Kemerer mistakenly identifies Maine, Rhode Island and Maryland as having No-Aid Provisions, none of which has ever had such an amendment.

Although DeForrest rightly acknowledges the "considerable diversity in language and scope" among No-Aid Provisions (DeForrest 2003, 555), his classification of the provisions into "Weak," "Moderate" and "Strong" identifies only 21 cases. DeForrest delineates a broad "Moderate" class that includes constitutions with weak language and exemptions alongside states prohibiting both direct and indirect aid in strident terms. For example, he includes Delaware's weak Article 10, Sections 3 and 5, which allows both "transportation of students of nonpublic, nonprofit Elementary and High Schools" and "that all real or personal property used for [public and private] school purposes, where the tuition is free, shall be exempt from taxation and assessment for public purposes," alongside Texas's much stronger Article 1, Section 7 "No money shall be appropriated, or drawn from the Treasury for the benefit of any sect, or religious society, theological or religious seminary; nor shall property belonging to the State be appropriated for any such purposes." DeForrest also mistakenly classifies New Jersey as a "Blaine Amendment" state.

In order to improve upon Kemerer and DeForrest's measures of No-Aid Provision strength, it is necessary to examine not only current state constitutions but also constitutions 
adopted in the past that have been superseded by new versions. Kemerer and DeForrest commit Type 1 errors by overzealously classifying No-Aid Provision states. Their confusion may result from the fact that in some states earlier versions of the constitution contained such an amendment but the provision is no longer included.

By checking the text of every state constitution, including superseded historical constitutions, this article draws upon a comprehensive list of No-Aid Provisions. ${ }^{2}$ Thirty-nine states and the District of Columbia have religious school aid bans. Of the eleven state constitutions that do not currently contain No-Aid Provisions, three - Arkansas, Louisiana and New Jersey - had them in earlier iterations. The amendments vary in length from a single sentence to several paragraphs. They also vary both in strength and the jurisprudential and political activity that has subsequently resulted in their clarification, fortification, weakening or overturning.

\section{Existing Explanations for No-Aid Provisions Adoption}

Legal scholars and historians have written extensively about the origins of the failed federal Blaine Amendment of 1876, but less about the origins of the state No-Aid Provisions. These are sometimes misleadingly referred to as "Little Blaine Amendments" (Bybee and Newton 2002) or "Baby Blaines" (Green 2004; Green 2008). The federal Blaine Amendment was introduced by the Republican former Speaker of the House James G. Blaine of Maine in late 1875 . Intended to be the $16^{\text {th }}$ Amendment of the Federal Constitution, it read:

\footnotetext{
"No state shall make any law respecting an establishment of religion or prohibiting the free exercise thereof; and no money raised by taxation in any state for the support of public schools, or derived from any public lands devoted thereto, shall ever be
}

\footnotetext{
${ }^{2}$ See online appendix for the full text of all No-Aid Provisions
} 
under the control of any religious sect, nor shall any money so raised or lands so devoted be divided between religious sects or denominations."

Blaine's Amendment passed after amendment in the House by a comfortable 180-7 but failed in the Senate. Blaine himself was absent from the final vote. Historians have indicated two main explanatory factors for the proposal and defeat of this federal Blaine Amendment:

First, Senator Blaine intended to derive personal political mileage from the Blaine Amendment during the 1876 Presidential nomination contest. Doubt has been cast upon Blaine's personal commitment to the substance of his own amendment (Gedicks 2004; Stern 2004), a suggestion substantiated by Blaine's absence from the vote once it became clear that Rutherford Hayes, rather than Blaine, would gain the Republican presidential nomination.

Secondly, the Republican Party was nervous about the upcoming elections with a greatly consolidated Democratic South and increased immigration of Catholic voters to the US, a group which had traditionally voted for the Democratic Party. Hence both Republican President Grant and Congressional members of the Republican Party supported the federal Blaine Amendment in an attempt to attract Southern Protestant Democrats and to portray Democratic Congressmen who voted against the Blaine Amendment as pro-Catholic, potentially a damaging attack at a time of widespread anti-Catholicism (Stern 2004; Green 2004). The attempt failed because House Democrats altered the federal Blaine Amendment and then voted for the amended version. Although there was an almost perfect party line vote on the federal Blaine Amendment in the Senate (Heytens 2000, 133), the Republicans could not use the federal Blaine Amendment against the Democrats in 1876.

The motives for the introduction of No-Aid Provisions in state constitutions are mixed. Several were introduced in state legislatures immediately following the failure of the federal Blaine Amendment and nine states had No-Aid Provisions incorporated into their 
state constitutions as part of a mandate imposed by Congress under the Enabling Acts of 1889, 1890, 1894, 1906 and 1910. These nine states - Montana, Washington and the Dakotas, Idaho, Utah, Oklahoma, New Mexico and Arizona - were required to pass such prohibitions as a condition for their entrance to the Union. Historians have suggested that in a context of increased industrialization, migration, and the difficulties of Reconstruction, religious school aid prohibitions were seen as vote-winners. These scholars emphasize the connection between No-Aid Provision passage and the "Common Schools Question," by which is meant the institutionalization of a system of non-sectarian public education that would educate all American children in democratic and republican ideals (Green 2004).

Commentators are divided as to the role of anti-Catholic sentiment in the passage of state No-Aid Provisions. Several have suggested that a "wave of anti-Catholic hysteria" (Heytens 2000, 134) was responsible, or at least "it cannot be denied that some of the rhetoric used in urging adoption of the Blaine Amendments in the nineteenth century was tainted by raw anti-Catholicism." (Stern 2004, 167) Others argue that, on the contrary, "the impulse toward non-sectarian public education was based on noble, republican ideals" and was "hijacked by Nativist groups for their bigoted aims." (Green 2004, 113) Green argues that No-Aid Provision passage "had as much to do with the partisan climate of the postReconstruction era and related concerns about federal power over education as it did with Catholic animus." (Green 2004, 114) The rise of the "Know-Nothings" in many states during the 1850 s coincided with a series of school funding controversies and a spike in No-Aid Provision passage, but historians are divided on the degree to which the Know-Nothings and their American Party were hostile to Catholics (Annbinder 1992; Overdyke 1950). Figure 1 shows the temporal distribution of No-Aid Provisions by decade of passage.

[FIGURE 1 ABOUT HERE] 
Adams argues that "the first Blaine-like constitutional amendment was passed by the KnowNothing Party in the cradle of the common school movement in Massachusetts." (Adams 2005, 12) Actually, four states had already passed such amendments by the time Massachusetts adopted its first No-Aid Provision, as Figure 1 shows. Michigan had even passed two. Adams's contention is that anti-Catholic Know-Nothings were responsible for No-Aid Provisions but this argument has been challenged.

Although scholars disagree about the explanatory role of anti-Catholic sentiment in relation to late nineteenth-century amendments, the role of partisanship is more widely accepted. Republican President Grant had urged the adoption of the federal Blaine Amendment, Republican Senator Blaine had sponsored it, Republicans in the Senate and House had overwhelmingly voted for the federal Blaine Amendment, and new Western states with Republican Governors were adopting No-Aid Provisions in their state constitutions. The New York Times observed of President Grant's 1875 speech that an "appeal to religious passions was worth twenty-five thousand votes to the Republicans" (Green 2004, 188). The Democratic Los Angeles Daily Herald said "this is unmistakeably an effort to drag religion into the political arena, and inflame the rancor of bigotry and sectarian zeal, that purely political parties may be disrupted and the GRANT party profit by the dissensions." (Bassett 1875)

These historical claims are well substantiated but limited in two ways: they consider only the causes of state No-Aid Provision adoption rather than the strength of the No-Aid Provisions adopted and they largely ignore the state No-Aid Provisions adopted in the twentieth century or the mid-nineteenth. Green rightly points out that the "no-funding principle and its corollary, non-sectarian education, predate the nineteenth century influx of Catholic immigration, the advent of parochial schooling, and the rise of organized nativism." 
(Green 2004, 113) Hence investigation of the causes of No-Aid Provisions should not be confined to the particular pressures and personalities of the Gilded Era.

Existing scholarly debates about the origins of state No-Aid Provisions raise a number of untested questions: were and are Republican states more likely to adopt No-Aid Provisions, and stronger ones? Do racial, religious or geographical factors make a difference? What are the most important determinants of the stringency of a state's prohibition of religious school aid? This paper tests these explanations statistically against a numerical scale of No-Aid Provisions strength.

\section{Constructing a No-Aid Provisions Scale}

State No-Aid Provisions were subjected to content analysis with five scoring criteria: indirect or direct aid, the tone of the provision, the extent of the bans, and any exclusions or qualifications. Johnson attempted to classify "Blaine Amendments" using the term "sectarian" (Johnson 2008) but this test was used only to indicate the presence of a "Blaine Amendment" rather than to rank them by strength. There are several reasons the term "sectarian" was not used as a scoring criterion in this content analysis: first, it encourages Type 2 Errors by ignoring many states with functioning, consequential religious school aid provisions; Johnson excluded sixteen states from his analysis including Massachusetts and Michigan, which have some of the strongest prohibitions of religious school aid (Duncan 2006). Secondly, the use of the term "sectarian" as a scoring criterion prejudices any investigation of the origins of No-Aid Provisions by assuming the language of late nineteenth-century anti-Catholicism.

Each No-Aid Provision was coded using five criteria. ${ }^{3}$ The first (A) is whether the amendment prohibits direct and/or indirect aid. "Direct aid" refers to the inclusion of

\footnotetext{
${ }^{3}$ See the online appendix Table 1a for full scoring by criterion.
} 
religious schools within the publicly funded school system, or in other words, state funding of religious schools through direct appropriation of tax-payer money. "Indirect aid" is a more contested concept. It refers to the provision of education-related services by the government for children at private religious schools, or to voucher schemes in which families are offered a publicly-funded sum to be spent on public or private school tuition. The aid is indirect because it is offered to the parent or child and not directly to the school. Some No-Aid Provisions explicitly state only that direct aid is prohibited. These amendments are coded as weaker than amendments that simply do not mention the language of directness or indirectness, because of the explicit inclusion of the weaker prohibition.

No-Aid Provisions were also grouped according to the tone of the language (B), whether "Strident," "Not Strident" or "Placatory." These assessments consider the use of absolutist language such as "whatever," "anything," "never," "all” or "none," and mollifying language such as "except," "not only," "not wholly," "no exclusive right" that focuses on support for public schools rather than the withdrawal of support for private ones. For instance, the stridency of Wyoming's Article 7, Section 12 "Sectarianism prohibited: No sectarian instruction, qualifications or tests shall be imparted, exacted, applied or in any manner tolerated in the schools of any grade or character controlled by the state, nor shall attendance be required at any religious service therein, nor shall any sectarian tenets or doctrines be taught or favored in any public school or institution that may be established under this constitution," can be contrasted with the relative mildness of Ohio's Article 6, Section 2 "The General Assembly shall make such provisions, by taxation, or otherwise, as, with the income arising from the school trust fund, will secure a thorough and efficient system of common schools throughout the state; but no religious or other sect, or sects, shall ever have any exclusive right to, or control of, any part of the school funds of this state." 
The third criterion (C) indicates how many types of aid to religious institutions are banned. The weakest No-Aid Provisions, such as Delaware's, ban only public appropriations, stronger ones, such as Minnesota's, ban both appropriations and property or land transfers, and the strongest amendments, such as Michigan's, have a long list of explicit bans, including tax exemptions as well as appropriations, credit, subsidies or vouchers.

The fourth criterion (D) includes two ways in which No-Aid Provisions can be weakened: through the inclusion of a general qualifying statement or official exemption to the religious school aid ban. In the former category are Colorado's Article 2, Section 4 "The free exercise and enjoyment of religious profession and worship, without discrimination, shall forever hereafter be guaranteed" or Wisconsin's Article 1, Section 18 "The right of every person to worship Almighty God according to the dictates of conscience shall never be infringed.” In the latter category are New York's Article 11, Section 3 “...but the legislature may provide for the transportation of children to and from any school or institution of learning," or Hawaii's Article 10, Section 1: “...except that proceeds of special purpose revenue bonds...may be appropriated to finance or assist...not-for-profit private nonsectarian and sectarian elementary schools, secondary schools, colleges and universities." The fifth group (E) contains the states that do not currently have a No-Aid Provisions.

All states were given 10 points and lost or retained points depending on their performance on each of the five criteria. The lack of a No-Aid Provision lost the state 10 points and gave it an automatic score of 0 on the $0-10$ scale. All points on the scale were possible, although no states were given a score of 1 or 10 , the lowest and highest scores available to states with No-Aid Provisions. An amendment that uses strident language, explicitly bans both direct and indirect aid and includes a long list of prohibitions would score 10. An amendment that explicitly targets only direct public appropriations, uses 
placatory language, and includes both a qualifying statement supportive of religion and explicit exemptions would score $1 .^{4}$

The $0-10$ scaling is arbitrary in that it is designed to capture relevant relative distances between stronger and weaker No-Aid Provision language. Each of the five dimensions captures one element of overall provision strength. The aim is to improve the validity of the measure by capturing several different elements that are used to assess the strength of written communications - both substantive and tonal. Inevitably individual interpretations will differ, but by utilizing ordinary understandings of tone and meaning the measure is more likely to capture differences of substantive interest than if it had used a technical criterion or one element alone. It is comprehensive. It is also less likely to commit Type 2 errors of classification. The five elements are not additive in the sense that they are all of one type; indeed, the content analysis was designed to capture several different elements of provision strength; but they are additive in the sense that everyday assessment of the strength of written communications is based upon an overall assessment that incorporates several diverse indicators (Kiousis 2004). Like all meaningful written documents No-Aid Provisions are multidimensional constructs, necessitating a multidimensional approach.

The fact that one cannot guarantee that the distance between 0 (No No-Aid Provision) and 1 (very weak No-Aid Provision) is the same as that between the other numbers makes it is necessary to proceed with caution when using these scores as interval-level variables, but given that many state constitutions make reference to religion and a No-Aid Provision scoring 1 would include at least one exemption and qualification it is not unreasonable to treat them along a unidimensional scale. ${ }^{5}$

An inter-code reliability test (ICRT) was conducted in order to test the validity of these scoring procedures, whereby four coders examined the same provisions independently.

\footnotetext{
${ }^{4}$ The scoring tables for the No-Aid Provisions are available in the online appendix in Table 1a.

${ }^{5}$ The online appendix Table $2 \mathrm{a}$ lists state No-Aid Provisions with full scoring. Table 3 a summarizes the No-Aid Provision score by state.
} 
The average ICRT score was $83.5 \%$, although the proportion of states coded in the same way as the original coding for Groups A, C and D was over $90 \%$ while the proportion coded similarly for Group B was between 60 and 70\%. This outcome is expected since Group B involves more normative judgements about tone than merely defining or counting words. Figure 2 shows the distribution of No-Aid Provision strength for the first No-Aid Provision each state passed:

\section{[FIGURE 2 ABOUT HERE]}

The weakest No-Aid Provisions, with scores of 2 and 3, are Nebraska, Delaware and Wisconsin. Montana and South Dakota are the strongest, scoring 9. The No-Aid Provision scoring table reveals how some state amendments have changed over time. No-Aid Provisions in Michigan, Mississippi, Massachusetts and Nevada strengthened as new state constitutions or amendments to previous constitutions were passed. In Michigan the strengthening is particularly obvious as each subsequent state constitution builds upon the language of previous ones, from a score of 5 in 1835 to 7 in 1850 to 8 with the passage of an especially strong constitutional amendment in 1970. Massachusetts rose from 6 to 8 between 1855 and 1917. Nevada and Mississippi rose from 6 to 7 between the 1860s and the 1890s.

In New York, Wisconsin and Delaware, by contrast, the No-Aid Provisions weakened with the passage of transportation exemptions, from a New York score of 7 in 1894 to 5 in 1938, a Wisconsin score of 5 in 1848 to 3 in 1967, and a Delaware score of 3 in 1897 to 2 in 1967. Nebraska passed an exemption for schools for the handicapped in 1976 and Utah added the word "direct" to its prohibition of aid in 1986, reducing their No-Aid Provision strength scores to 2 and 4 respectively. Three of the states that currently do not have No-Aid Provisions: Arkansas, New Jersey and Louisiana, once had mid-ranking No-Aid Provisions with scores of 6 for Arkansas and Louisiana and 5 for New Jersey. 
Most No-Aid Provisions strengthening occurred during the nineteenth century and the weakening and elimination of No-Aid Provisions has become more common over the twentieth century, as Table 1 shows. A failed Floridian ballot initiative in November 2012 was the latest of a series of challenges to No-Aid Provisions, the most famous of which was Justice Thomas's opinion in Mitchell v Helms. Justice Thomas argued that the exclusion of pervasively sectarian schools from aid programmes was a doctrine "born of bigotry" that "should be buried now" (Thomas 2000, 530:6). Many criticisms of No-Aid Provisions rest on a particular understanding of their birth. If No-Aid Provisions were created for bad reasons, claim the critics, their elimination should be welcomed. Thus modern attempts to eliminate No-Aid Provisions cannot be comprehended without an understanding of their origins.

\section{[TABLE 1 ABOUT HERE]}

\section{Explaining No-Aid Provision Strength}

To re-cap, historians have told three main stories about the origins of No-Aid Provisions: Republicans, Catholics and the West. The first is that Republican dominance of state offices encouraged the passage of No-Aid Provisions; the second is that anti-Catholic sentiment drove No-Aid Provision adoption; the third is that after the failure of the federal Blaine Amendment, Federal Enabling Acts mandated "Baby Blaine" adoption for Western states. The third story must be true because states could not be admitted to the Union without a No-Aid Provision in the new state constitution, but it is a far more contestable proposition that the bald requirement to adopt a state No-Aid Provision also encouraged the adoption of stronger No-Aid Provisions. It is possible that there was resentment from new Western states (particularly those such as Utah whose statehood efforts had previously been rebuffed) at lengthy Enabling Act requirements created by the federal Congress, an attitude conducive to the weakening of the subsequent state No-Aid Provision. The three hypotheses are as follows: 
H1: Republican control of state offices at the time of No-Aid Provision passage increases NoAid Provision strength

Using Dubin's year-by-year summary of historical partisan affiliations in state legislatures (Dubin 2007), data on the proportions of Republican seats in each house of the state legislature were combined with data on Republican control of state governorships to yield a full picture of partisan control in each state at the time of No-Aid Provision passage. For states whose first constitution contained a No-Aid Provision, the party that first took control of the state offices after the creation of the state was used. Where No-Aid Provision passage occurred in an election year, this variable refers to the party in control at the time of provision passage.

H2: A large Catholic presence as a proportion of the state population increases No-Aid Provision strength.

Since individual religious identification questions were not asked by census-gatherers until 1890, historians have found gathering data about early religious populations challenging (Finke and Stark 1992). Between 1850 and 1946 census-gatherers counted church edifices and organizations, their total seating capacity or "aggregate accommodations" and the total value of the church-owned assets for each denomination (The Association of Religion Data Archives 2012). From 1890 these church-census questions were asked alongside individual religious identification questions, so a Cronbach Alpha test was conducted for 1890 data to find the church-level measure that was most consistent with the measure of the Catholic population. Table 2 shows the results for the internal consistency of scales consisting in the proportion of the population that was Catholic and the proportion of total edifices, organizations, seating capacity and property value belonging to the Catholic Church in each state. The best Cronbach's Alpha result, 0.84, of the four church census categories prior to 
1890 was for Catholic Church seating capacity. This high level of consistency offers reasonable confidence in the estimation of Catholic population. For each state, the closest census data to the date on which the No-Aid Provision was passed was used. For the majority of states, where No-Aid Provisions were passed prior to 1890, total Catholic seating capacity was calculated as a proportion of the total seating capacity of the churches of all religious denominations in the state. This measure was used as a proxy for the proportion of Catholics in the state.

\section{[TABLE 2 ABOUT HERE]}

One possible difficulty is that endogeneity might be expected between the proportion of Catholics in a state's population and the strength of its No-Aid Provision. A weaker NoAid Provision might be proposed because Catholics arrive in the state or Catholics might arrive in the state because the state has a weaker No-Aid Provision. This investigation copes with possible endogeneity by using the census data for the closest year to No-Aid Provision passage and where there is a choice, the date immediately before rather than after the Provision passage. Since the cause must occur before the effect, such procedures help mitigate endogeneity concerns.

\section{H3: The requirements of the Federal Enabling Acts increase No-Aid Provision strength}

A dummy variable for states subject to Federal Enabling Acts is also tested against the No-Aid Provision strength score. Although it is possible that Federal Enabling Act requirements might either increase No-Aid Provision strength by encouraging states to adopt strongly worded statements, or increase resentment and thereby decrease No-Aid Provision strength, one might think states controlled by Democrats would react differently to states controlled by Republicans. If historians are right to suggest that partisanship matters and the No-Aid Provisions were overwhelmingly Republican, then it is possible that where Enabling 
Acts mandated No-Aid Provisions, Republican states enacted stronger ones while Democratic states enacted weaker ones. Of the four Federal Congresses who passed these nine Enabling Acts, the $51^{\text {st }}, 59^{\text {th }}$ and $61^{\text {st }}$ all had unified Republican control and only one, the $53^{\text {rd }}$ Congress, 1893-5, was controlled by Democrats. An interaction term is included in the regression between the partisanship and Federal Enabling Act variables.

\section{Some Caveats}

Since there are only fifty-one cases in the dataset, efforts were made to avoid degrees of freedom problems but all results should be treated with caution nevertheless. The $\mathrm{N}$ must remain low because it contains the full universe of cases, that is, the first No-Aid Provision each state adopted. The unit of analysis is state-year, which means that all data relates to the year of original No-Aid Provision passage in each state. Changes to No-Aid Provisions are so infrequent and few in number that the time series analysis option was rejected. Clarke's trenchant criticisms of the inclusion of excessive controls to forestall omitted variable bias (Clarke 2005) are relevant here because the broad historical spread necessitates selection of only a limited number of all potential control variables for inclusion in the model. Coupled with potential degrees of freedom problems, the danger of introducing further inefficiency and bias required that the models be fairly narrowly specified (L. F. Lee 1982). Region, for instance, was not included as a control variable because its inclusion would signify a causal significance, a kind of mystical exceptionalism, which obscures rather than illuminates.

For the eight states that have never adopted a No-Aid Provision and are coded 0: Tennessee, Connecticut, North Carolina, Maine, Maryland, Rhode Island, West Virginia and Vermont, all relevant data that is tied to No-Aid Provision passage was approximated to the closest possible date for these states. For those states that adopted a new constitution during the time that new No-Aid Provisions were being passed in other states (1835-1959), the year 
of this constitution was taken as the relevant date for partisan and religious information: Maryland (1867), Rhode Island (1843), Tennessee (1870), North Carolina (1868) and West Virginia (1872). For 0 states whose constitutions were passed either before 1835 or after 1959: Connecticut (whose two constitutions were passed in 1638 and 1965), Maine (1820) and Vermont (1793), the year 1875 was taken as the relevant year since it is the middle of the decade in which the federal Blaine Amendment failed and the largest number of No-Aid Provisions were passed. This measure is imperfect, both as a result of such data problems and the difficulty of treating states without a No-Aid Provision similarly to those with one. However, by running models under multiple specifications, with and without the cases coded 0 , the analysis differentiates between factors affecting No-Aid Provision adoption and factors affecting their strength, as shown in Tables 3 and 4 in the next section.

\section{Results}

The evidence suggests that credence should be given to at least two of these hypotheses but the relationship between Republicans, Catholics and the West and the strength of No-Aid Provisions is more complex than has been suggested by some scholars. The following tables report ordinary least-squares linear regression results with robust standard errors.

\section{[TABLES 3 and 4 ABOUT HERE]}

Table 3 shows the model building (1.1-1.6) from univariate to multivariate analysis using all cases, including states which have never passed a No-Aid Provision. Table 4 shows the same process (2.1-2.6) excluding such states. In both cases the proportion of Catholics in 
the population and the presence of Federal Enabling Act requirements increase No-Aid Provision strength, but the results for partisan control of the state offices are not significant. ${ }^{6}$

Including cases with no No-Aid Provisions, the proportion of Catholics in a state's population at the time of No-Aid Provision passage increases the strength of the No-Aid Provision adopted by 0.05 on the $0-10$ scale for every percentage increase in Catholics. To illustrate: for states subject to Federal Enabling Act requirements, those with a population that is $20 \%$ Catholic are expected to have an NAP strength score of 7 . States that are $40 \%$ Catholic are expected to have an NAP strength score of 8. For states without Federal Enabling Act requirements, the respective scores are 5 for states that are $20 \%$ Catholic and 6 for states that are $40 \%$ Catholic.

Contrary to the suggestion that the demands of the Federal Enabling Acts engendered resentment and laxer compliance with the No-Aid Provision requirements, the obligation for territories entering the Union to adopt a No-Aid Provision as part of their first constitution not only caused all aspirant states to adopt such provisions, but to adopt stronger ones by a factor of more than two points on the 0-10 scale, according to Models 1.5 and 2.5. Where states without No-Aid Provisions are excluded the co-efficient is slightly smaller but the effect is the same: Catholics and Federal Enabling Act requirements increase No-Aid Provision strength.

When further interaction effects are considered in Models 1.6 and 2.6 some interesting partisan effects emerge. To make interpretation easier, the dummy for Republican control of all state offices was reversed in the last line of Models 1.6 and 2.6 to show the effect of Democratic control of at least one state office. This coefficient is simply the reverse of the coefficient for the Republican control of all state offices dummy; the sign is inverted. Controlling for the interaction between the Federal Enabling Act dummy and the reverse of

\footnotetext{
${ }^{6}$ Models 1.5, 2.5 and 1.6 are displayed in online appendix Table 4a, which summarizes the main results.
} 
the dummy for Republican control of all state offices, Model 1.6 in Table 3 shows an increase of 3.5 points on the No-Aid Provision strength scale associated with Republican control of all state offices.

Moreover, Model 2.6 in Table 4 displays a three-point increase in No-Aid Provision strength (excluding states without a No-Aid Provision) where a Federal Enabling Act requirement is combined with at least one of the state offices (Governor, Upper and Lower House) under Democratic control. This puzzling result suggests that, contrary to the resentment-theory, Democratic states were prompted by Federal Enabling Act requirements to increase the strength of their No-Aid Provision. The explanation might be that since Republican control already increases No-Aid Provision strength, it is for Democratic states that the Federal Enabling Act strictures were most effective in raising No-Aid Provision strength.

\section{Conclusion}

Apart from the creation of the first quantitative No-Aid Provision strength scale, this paper has several further advantages over the existing accounts of No-Aid Provisions: effect magnitude and adjudication. The study does not merely confirm the findings of the historical literature; it demonstrates for the first time the magnitude of the effects of commonly cited factors (partisanship, Catholic population and Enabling Act requirements) on No-Aid Provision strength. It also adjudicates between competing explanations for No-Aid Provision strength and adoption: Enabling Act strictures and Catholic populations increase No-Aid Provision strength. The presence of an Enabling Act has roughly the effect of a fortypercentage increase in Catholic population as a proportion of the total population, since each adds an average treatment effect of two points on the 0-10 No-Aid Provision strength scale. 
There is insufficient evidence to reject the null hypothesis for the Republican partisanship variable when controlling merely for Catholic population and Enabling Acts. But when interaction terms are added, a move not made explicitly by the existing historical accounts, Republican control of state offices increases No-Aid Provision strength. States under Democratic control also increase No-Aid Provision strength when forced to adopt a No-Aid Provision by a Federal Enabling Act.

This paper establishes the importance of Republicans, Catholics and the West in the creation of No-Aid Provisions. The new scale of No-Aid Provision strength can be used to conduct meaningful investigation about the causes and consequences of No-Aid Provision adoption. Such investigations have ramifications for all citizens, whether they are members of religious groups, educators, parents or simply tax-payers, because they affect our understanding of the appropriate role of religion in public life and the degree to which religious organizations should benefit from tax-payer funds.

The construction of a No-Aid Provision strength scale not only facilitates investigation of the creation of No-Aid Provisions but also their amendment and repeal. In November 2012 Florida's citizens rejected Ballot Initiative 8, a proposal to eliminate the Floridian No-Aid language and replace it with "No individual or entity may be discriminated against or barred from receiving funding on the basis of religious identity or belief." (Florida Department of State, Division of Elections; Plakon and Precourt 2011) Just as this analysis shows for the origins of No-Aid Provisions, Catholics were prominent amongst those petitioning for No-Aid Provision elimination (Alvarez 2012). However Republicans were also amongst those calling for repeal of the No-Aid Provision which, as this paper reveals, is an historical volte-face.

With the failure of the Florida initiative, the number of states that have weakened or eliminated their No-Aid Provisions stands currently at seven but the Florida initiative will not 
be the last such attempt. Garnett argues "these provisions should be confronted not only as historical artefacts, as evidence of long-dead biases, or as the latest hurdles in voucher related litigation. Instead, they should be engaged as moves in important and on-going arguments about faith, authority, and democracy." (Garnett 2004, 71) In the current polarized political climate, interest groups use state legal provisions to lobby for major educational reforms and there is heightened pressure on constitutional provisions on religious freedom and aid for religious organizations. This timely investigation of No-Aid Provision strength is vital for scholarly engagement with the turbulent politics of the church-state boundary. 


\section{References}

Adams, N.A. 2005. "Pedigree of an Unusual Blaine Amendment: Article 1, Section 3 Interpreted and Implemented in Florida Education." Nova Law Review 30 (1): 1-74.

Adkinson, D.M., and L.M Palmer. 2011. The Oklahoma State Constitution. The Oxford Commentaries on the State Constitutions of the United States. New York: Oxford University Press.

Alvarez, L. 2012. "Voters in Florida Are Set to Weigh In on Two Contentious Ballot Questions." The New York Times, October 6, sec. U.S. http://www.nytimes.com/2012/10/07/us/floridians-face-initiatives-on-abortion-andchurch-and-state.html.

Annbinder, T. 1992. Nativism and Slavery: The Northern Know-Nothings and the Politics of the 1850s. New York and Oxford: Oxford University Press.

Arend, J.J. 1961. Matthews v Quinton, 362 P.2d 932. Alaska Supreme Court.

Bassett, J.M. 1875. “Grant's Religious Plank.” Los Angeles Daily Herald, October 13.

Bastress, R.M. 2011. The West Virginia State Constitution. The Oxford Commentaries on the State Constitutions of the United States. New York: Oxford University Press.

Bowers, M.W. 2011. The Nevada State Constitution. The Oxford Commentaries on the State Constitutions of the United States. New York: Oxford University Press.

Bybee, J.S., and D.W. Newton. 2002. "Of Orphans and Vouchers: Nevada's 'Little Blaine Amendment' and the Future of Religious Participation in Public Programs." Nevada Law Journal 2: 551-589.

Clarke, K.A. 2005. "The Phantom Menace: Omitted Variable Bias in Econometric Research." Conflict Management and Peace Science 22 (4).

Collins, R, and D.A. Oesterle. 2011. The Colorado State Constitution. The Oxford Commentaries on the State Constitutions of the United States. New York: Oxford University Press.

Conley, P.T., and R.G. Flanders. 2011. The Rhode Island State Constitution. The Oxford Commentaries on the State Constitutions of the United States. New York: Oxford University Press.

Crowley, D.W., and F.A. Heffron. 2011. The Idaho State Constitution. The Oxford Commentaries on the State Constitutions of the United States. New York: Oxford University Press.

D'Alemberte, T. 2011. The Florida State Constitution. The Oxford Commentaries on the State Constitutions of the United States. New York: Oxford University Press.

DeForrest, M.E. 2003. "An Overview and Evalutaion of State Blaine Amendments: Origins, Scope, and First Amendment Concerns." Harvard Journal of Law and Public Policy 26: 551-626.

Dinan, J.J. 2011. The Virginia State Constitution. The Oxford Commentaries on the State Constitutions of the United States. New York: Oxford University Press.

Dubin, M.J. 2007. Party Affiliations in the State Legislatures: A Year By Year Summary, 1796-2006. Jefferson, North Carolina and London: McFarland and Company, Inc.

Duncan, K. 2006. “Secularism's Laws: State Blaine Amendments and Religious Persecution." Bepress Legal Series 26.

Elison, L.M., and F Snyder. 2011. The Montana State Constitution. The Oxford Commentaries on the State Constitutions of the United States. New York: Oxford University Press.

Finke, R, and R Stark. 1992. The Churching of America, 1776-1990: Winners and Losers in Our Religious Economy. New Brunswick, N.J: Rutgers University Press. 
Fino, S.P. 2011. The Michigan State Constitution. The Oxford Commentaries on the State Constitutions of the United States. New York: Oxford University Press.

Florida Department of State, Division of Elections. "Religious Freedom Ballot Initiative." http://election.dos.state.fl.us/initiatives/initdetail.asp?account $=10 \&$ seqnum $=86$.

Friedman, D. 2011. The Maryland State Constitution. The Oxford Commentaries on the State Constitutions of the United States. New York: Oxford University Press.

Friedman, L, and L Thody. 2011. The Massachusetts State Constitution. The Oxford Commentaries on the State Constitutions of the United States. New York: Oxford University Press.

Fusarelli, L D. 2003. The Political Dynamics of School Choice: Negotiating Contested Terrain. New York and London: Palgrave Macmillan.

Galie, P.J. 2011. The New York State Constitution. The Oxford Commentaries on the State Constitutions of the United States. New York: Oxford University Press.

Garnett, R.W. 2004. "The Theology of the Blaine Amendments." First Amendment Law Review 2: 45-84.

Gedicks, F.M. 2004. "Reconstructing the Blaine Amendments." First Amendment Law Review 2: 85-106.

Goss, K.C. 2011. The Arkansas State Constitution. The Oxford Commentaries on the State Constitutions of the United States. New York: Oxford University Press.

Graham, C.B. 2011. The South Carolina State Constitution. The Oxford Commentaries on the State Constitutions of the United States. New York: Oxford University Press.

Green, S.K. 2004. "“Blaming Blaine': Understanding the Blaine Amendment and the 'No Funding' Principle." First Amendment Law Review 2: 107-152. . 2008. "The Insignificance of the Blaine Amendment." Brigham Young University Law Review: 295-333.

. 2012. The Bible, the School, and the Constitution. New York: Oxford University Press.

Grodin, J.R., C.R. Massey, and R.B. Cunningham. 2011. The California State Constitution. The Oxford Commentaries on the State Constitutions of the United States. New York: Oxford University Press.

Hargrave, W.L. 2011. The Louisiana State Constitution. The Oxford Commentaries on the State Constitutions of the United States. New York: Oxford University Press.

Heller, F.H. 2011. The Kansas State Constitution. The Oxford Commentaries on the State Constitutions of the United States. New York: Oxford University Press.

Heytens, T.J. 2000. "School Choice and State Constitutions." Virginia Law Review 86: 117162.

Hill, M.B. 2011. The Georgia State Constitution. The Oxford Commentaries on the State Constitutions of the United States. New York: Oxford University Press.

Hill, W.C. 2011. The Vermont State Constitution. The Oxford Commentaries on the State Constitutions of the United States. New York: Oxford University Press.

Holland, R.J. 2011. The Delaware State Constitution. The Oxford Commentaries on the State Constitutions of the United States. New York: Oxford University Press.

Horton, W.W. 2011. The Connecticut State Constitution. The Oxford Commentaries on the State Constitutions of the United States. New York: Oxford University Press.

Ireland, R.M. 2011. The Kentucky State Constitution. The Oxford Commentaries on the State Constitutions of the United States. New York: Oxford University Press.

Jefferson, T. 1802. "Jefferson's Letter to the Danbury Baptists". Library of Congress. http://www.loc.gov/loc/lcib/9806/danpre.html.

Johnson, D.F. 2008. "State Blaine Amendments: Origins, History, and Education Policy Implications Following Mitchell, Zelman, and Locke". Florida: University of Florida. 
Keiter, R.B., and T Newcomb. 2011. The Wyoming State Constitution. The Oxford Commentaries on the State Constitutions of the United States. New York: Oxford University Press.

Kemerer, F.R. 1997. "The Constitutional Dimension of School Vouchers." Texas Forum on Civil Liberties and Civil Rights 3: 137-186.

Kinzer, D.L. 1964. An Episode in Anti-Catholicism: The American Protective Association. Seattle: University of Washington Press.

Kiousis, S. 2004. "Explicating Media Salience: A Factor Analysis of New York Times Issues Coverage During the 2000 U.S. Presidential Election." Journal of Communication 54 (1): 71-87.

Laska, L.L. 2011. The Tennessee State Constitution. The Oxford Commentaries on the State Constitutions of the United States. New York: Oxford University Press.

Leach, J. 1968. Honohan v Holt, 17 Ohio 57. Common Pleas Court of Franklin County. Leahy, J.E. 2011. The North Dakota State Constitution. The Oxford Commentaries on the State Constitutions of the United States. New York: Oxford University Press.

Lee, A.F. 2011. The Hawaii State Constitution. The Oxford Commentaries on the State Constitutions of the United States. New York: Oxford University Press.

Lee, L.F. 1982. "Specification Error in Multinomial Logit Models: Analysis of the Omitted Variable Bias." Journal of Econometrics 20 (2) (November): 197-209.

Leshy, J.D. 2011. The Arizona State Constitution. The Oxford Commentaries on the State Constitutions of the United States. New York: Oxford University Press.

Lousin, A. 2011. The Illinois State Constitution. The Oxford Commentaries on the State Constitutions of the United States. New York: Oxford University Press.

Marshall, S. 2011. The New Hampshire State Constitution. The Oxford Commentaries on the State Constitutions of the United States. New York: Oxford University Press.

May, J.C. 2011. The Texas State Constitution. The Oxford Commentaries on the State Constitutions of the United States. New York: Oxford University Press.

McBeath, G.A. 2011. The Alaska State Constitution. The Oxford Commentaries on the State Constitutions of the United States. New York: Oxford University Press.

McLauchlan, W.P. 2011. The Indiana State Constitution. The Oxford Commentaries on the State Constitutions of the United States. New York: Oxford University Press.

Miewald, R.D., and P.J. Longo. 2011. The Nebraska State Constitution. The Oxford Commentaries on the State Constitutions of the United States. New York: Oxford University Press.

Orth, J.V. 2011. The North Carolina State Constitution. The Oxford Commentaries on the State Constitutions of the United States. New York: Oxford University Press.

Overdyke, W.D. 1950. The Know-Nothing Party in the South. Louisiana: Louisiana State University Press.

Peterson, P E., and D E Campbell. 2001. Charters, Vouchers, and Public Education. Washington DC: The Brookings Institution.

Plakon, and Precourt. 2011. CS/HJR 1471 Religious Freedom. CS/HJR.

Smith, C.E. 2011. The New Mexico State Constitution. The Oxford Commentaries on the State Constitutions of the United States. New York: Oxford University Press.

Stark, J. 2011a. The Iowa State Constitution. The Oxford Commentaries on the State Constitutions of the United States. New York: Oxford University Press.

. 2011b. The Wisconsin State Constitution. The Oxford Commentaries on the State Constitutions of the United States. New York: Oxford University Press.

Steinglass, S.H., and G.J. Scarselli. 2011. The Ohio State Constitution. The Oxford Commentaries on the State Constitutions of the United States. New York: Oxford University Press. 
Stern, M.D. 2004. "Blaine Amendments, Anti-Catholicism, and Catholic Dogma." First Amendment Law Review 2: 153-178.

Stewart, W.H. 2011. The Alabama State Constitution. The Oxford Commentaries on the State Constitutions of the United States. New York: Oxford University Press.

The Association of Religion Data Archives. 2012. "The Data Were Downloaded from the Association of Religion Data Archives, www.TheARDA.com, and Were Collected by the Department of the Interior, Census Office."

Thomas, C. 2000. Mitchell v Helms, 530 U.S. 793.

Tinkle, M.J. 2011. The Maine State Constitution. The Oxford Commentaries on the State Constitutions of the United States. New York: Oxford University Press.

Utter, R.F., and H.D. Spitzer. 2011. The Washington State Constitution. The Oxford Commentaries on the State Constitutions of the United States. New York: Oxford University Press.

White, J.B. 2011. The Utah State Constitution. The Oxford Commentaries on the State Constitutions of the United States. New York: Oxford University Press.

Winkle, J.W. 2011. The Mississippi Constitution. The Oxford Commentaries on the State Constitutions of the United States. New York: Oxford University Press. 
Figure 1: New No-Aid Provisions by Decade

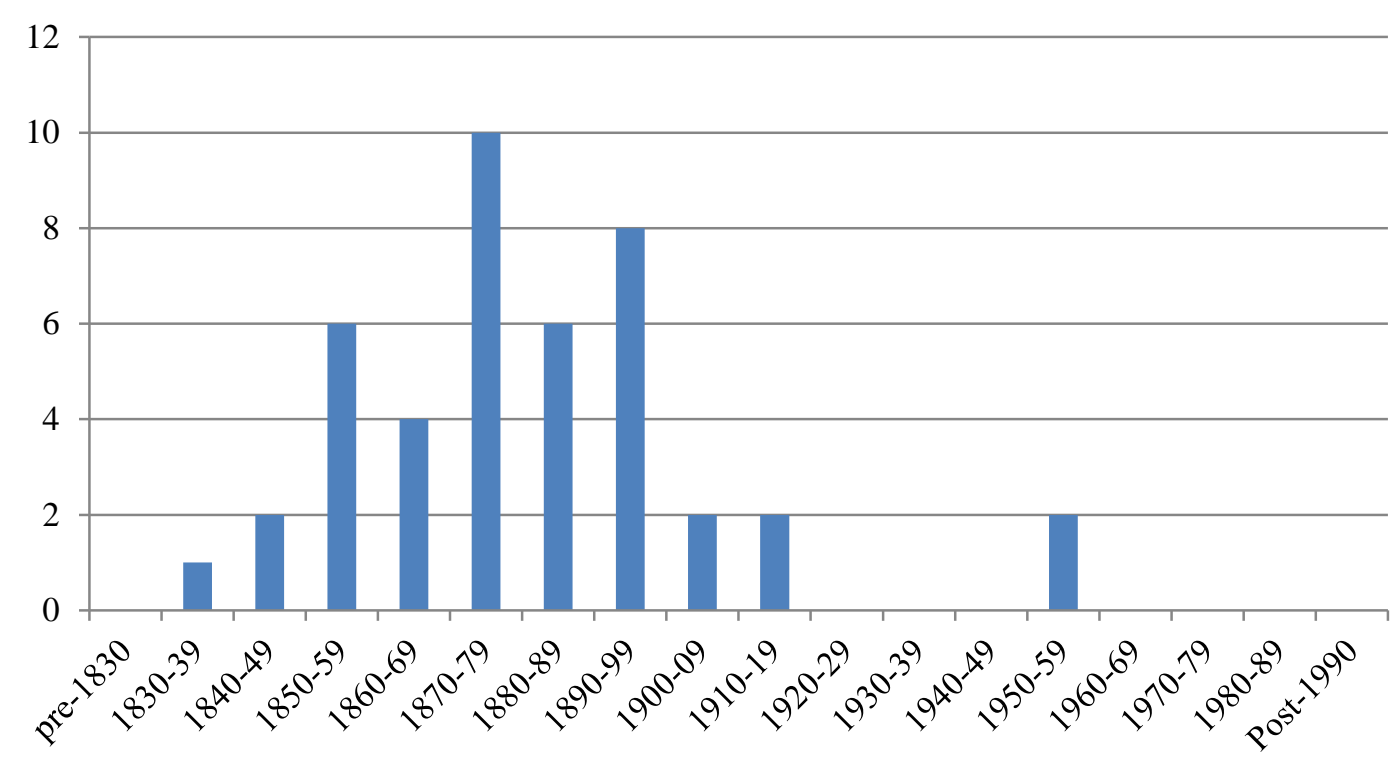


Figure 2: No-Aid Provision strength by state

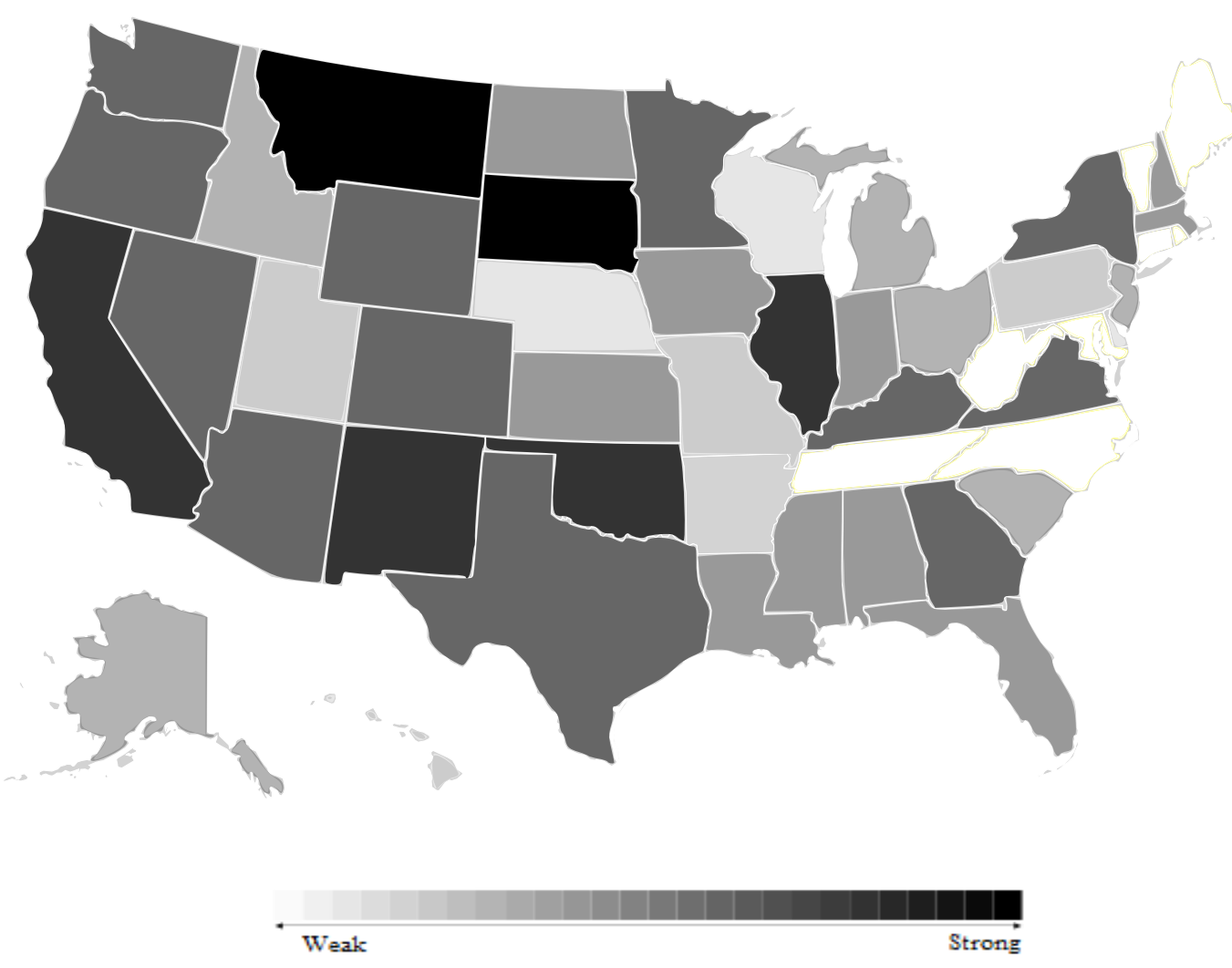


Table 1: No-Aid Provision introduction, change and elimination by decade

\begin{tabular}{lcccccccc} 
Decade & NEW & ACT & AVS & STR & WEA & ELIM & CTA & TOT \\
\hline Pre-1830 & 0 & 0 & - & 0 & 0 & 0 & 0 & 0 \\
$1830-39$ & 1 & 1 & 5 & 0 & 0 & 0 & 1 & 1 \\
$1840-49$ & 2 & 2 & 5 & 0 & 0 & 0 & 3 & 3 \\
$1850-59$ & 6 & 7 & 6.1 & 1 & 0 & 0 & 10 & 9 \\
$1860-69$ & 4 & 4 & 6 & 0 & 0 & 0 & 14 & 13 \\
$1870-79$ & 10 & 11 & 5.9 & 0 & 0 & 1 & 24 & 22 \\
$1880-89$ & 6 & 7 & 7.4 & 1 & 0 & 0 & 31 & 28 \\
$1890-99$ & 8 & 9 & 6 & 1 & 0 & 0 & 40 & 36 \\
$1900-09$ & 2 & 2 & 7.5 & 0 & 0 & 0 & 42 & 38 \\
$1910-19$ & 2 & 3 & 7.7 & 1 & 0 & 0 & 45 & 40 \\
$1920-29$ & 0 & 0 & - & 0 & 0 & 0 & 45 & 40 \\
$1930-39$ & 0 & 1 & 5 & 0 & 1 & 0 & 46 & 40 \\
$1940-49$ & 0 & 1 & - & 0 & 0 & 1 & 45 & 39 \\
$1950-59$ & 2 & 2 & 4.5 & 0 & 0 & 0 & 47 & 41 \\
$1960-69$ & 0 & 2 & 2.5 & 0 & 2 & 0 & 49 & 41 \\
$1970-79$ & 0 & 4 & 5 & 1 & 1 & 1 & 49 & 40 \\
$1980-89$ & 0 & 1 & 4 & 0 & 1 & 0 & 49 & 40 \\
Post-1990 & 0 & 0 & - & 0 & 0 & 0 & 49 & 40 \\
\hline
\end{tabular}

Table Key

\begin{tabular}{ll}
\hline NEW & New No-Aid Provision passed in decade \\
ACT & All No-Aid activity by decade \\
AVS & Average strength score of No-Aid Provisions passed in decade \\
STR & Number of No-Aid Provisions strengthened in decade \\
WEA & Number of No-Aid Provisions weakened in decade \\
ELIM & $\begin{array}{l}\text { Number of No-Aid Provisions eliminated in new constitution passed in decade } \\
\text { CTA }\end{array}$ \\
$\begin{array}{l}\text { Cumulative total of all new No-Aid Provisions passed and changes to No-Aid Provisions, both } \\
\text { weakening and strengthening }\end{array}$ \\
TOT & $\begin{array}{l}\text { Cumulative total of No-Aid Provisions excluding old No-Aid Provisions when superseded or } \\
\text { eliminated. Does not include revisions to existing No-Aid Provisions }\end{array}$ \\
\hline
\end{tabular}


Table 2: Cronbach's Alpha results for 1890: Level of consistency between church-level measures and the proportion of Catholics in the state population

Indicator of Catholic population for $\mathbf{1 8 9 0}$

Cronbach's Alpha

Catholic church organizations

0.77

Catholic church edifices

0.77

Total seating capacity of Catholic churches

0.84

Total value of Catholic church property

0.69 
Table 4: OLS regression for No-Aid Provision strength, with robust standard errors and unstandardized coefficients

\begin{tabular}{|c|c|c|c|c|c|c|}
\hline \multirow[b]{2}{*}{ Variable } & \multicolumn{5}{|c|}{ Model } & \multirow[b]{2}{*}{1.6} \\
\hline & 1.1 & 1.2 & 1.3 & 1.4 & 1.5 & \\
\hline $\begin{array}{l}\text { Proportion of } \\
\text { Catholics in state }\end{array}$ & $0.058 * * *$ & $0.054 * * *$ & $0.052 * * *$ & $0.054 * * *$ & $0.055 * * *$ & $0.058 * * *$ \\
\hline Federal Enabling Act & & $2.198 * * *$ & $1.997 * * *$ & $2.113 * * *$ & $2.110 * * *$ & 1.038 \\
\hline $\begin{array}{l}\text { Republican } \\
\text { Governorship }\end{array}$ & & & 0.504 & 0.560 & -0.569 & -1.154 \\
\hline $\begin{array}{l}\text { Republican control of } \\
\text { legislature }\end{array}$ & & & & -0.348 & -1.903 & -1.806 \\
\hline Governor*Legislature & & & & & 2.651 & $3.532 * *$ \\
\hline $\begin{array}{l}\text { Federal Enabling } \\
\text { Act*Democratic } \\
\text { control of an office }\end{array}$ & & & & & & 3.091 \\
\hline Constant & $4.439 * * *$ & $4.096 * * *$ & $3.901 * * *$ & $3.933 * * *$ & $4.189 * * *$ & $4.051 * * *$ \\
\hline & $\begin{array}{l}\mathrm{N}: 50 \\
\mathrm{R}^{2}: 0.09\end{array}$ & $\begin{array}{l}\mathrm{N}: 50 \\
\mathrm{R}^{2}: 0.20\end{array}$ & $\begin{array}{l}\mathrm{N}: 50 \\
\mathrm{R}^{2}: 0.21\end{array}$ & $\begin{array}{l}\mathrm{N}: 50 \\
\mathrm{R}^{2}: 0.22\end{array}$ & $\begin{array}{c}\mathrm{N}: 50 \\
\mathrm{R}^{2}: 0.26\end{array}$ & $\begin{array}{l}\mathrm{N}: 50 \\
\mathrm{R}^{2}: 0.30\end{array}$ \\
\hline
\end{tabular}


Table 5: OLS regression for No-Aid Provision strength with robust standard errors and unstandardized coefficients, excluding states without a No-Aid Provision

\begin{tabular}{|c|c|c|c|c|c|c|}
\hline \multirow[b]{2}{*}{ Variable } & \multicolumn{5}{|c|}{ Model } & \multirow[b]{2}{*}{2.6} \\
\hline & 2.1 & 2.2 & 2.3 & 2.4 & 2.5 & \\
\hline $\begin{array}{l}\text { Proportion of } \\
\text { Catholics in state }\end{array}$ & $0.022 * *$ & $0.022 * *$ & $0.020 * *$ & $0.021 * *$ & $0.021 * *$ & $0.025 * * *$ \\
\hline Federal Enabling Act & & $1.163 * *$ & $1.043^{*}$ & $1.174 * *$ & $1.175^{* *}$ & 0.278 \\
\hline $\begin{array}{l}\text { Republican } \\
\text { Governorship }\end{array}$ & & & 0.310 & -0.035 & -0.112 & -0.731 \\
\hline $\begin{array}{l}\text { Republican control of } \\
\text { legislature }\end{array}$ & & & & 0.320 & 0.159 & 0.240 \\
\hline Governor*Legislature & & & & & 0.234 & 1.139 \\
\hline $\begin{array}{l}\text { Federal Enabling } \\
\text { Act*Democratic } \\
\text { control of an office }\end{array}$ & & & & & & $2.648 * *$ \\
\hline Constant & $5.861 * * *$ & $5.622 * * *$ & $5.500 * * *$ & $5.441 * * *$ & $5.456 * * *$ & $5.309 * * *$ \\
\hline & $\mathrm{N}: 43$ & $\mathrm{~N}: 43$ & $\mathrm{~N}: 43$ & $\mathrm{~N}: 42$ & $\mathrm{~N}: 42$ & $\mathrm{~N}: 42$ \\
\hline & $\mathrm{R}^{2}: 0.05$ & $\mathrm{R}^{2}: 0.17$ & $\mathrm{R}^{2}: 0.18$ & $\mathrm{R}^{2}: 0.21$ & $\mathrm{R}^{2}: 0.21$ & $\mathrm{R}^{2}: 0.34$ \\
\hline
\end{tabular}

